\title{
Subretinal and Retrolaminar Migration of Intraocular Silicone Oil Detected on CT
}

\author{
(D) M. Abdalkader, (D). Takumi, (D) M.N. Chapman, (D) G.D. Barest, (D) C. Peeler, and (D). Sakai
}

\begin{abstract}
BACKGROUND AND PURPOSE: Intraocular silicone oil injection has been used to treat complicated retinal detachments, and recently its retrolaminar and intracranial migration has been reported. The purpose of this study was to document the prevalence of posterior migration of intraocular silicone oil on head CT and describe the clinical and radiologic findings.
\end{abstract}

MATERIALS AND METHODS: This retrospective study included 57 patients with intraocular silicone oil injection who underwent unenhanced head CT between November 2008 and July 2018. All images were visually evaluated for subretinal and retrolaminar migration of intraocular silicone oil involving the anterior visual pathway (optic nerve, optic chiasm, and optic tract) and the ventricular system. Attenuation values of those structures were measured and compared with those of the contralateral or adjacent normal structures.

RESULTS: We detected subretinal and retrolaminar silicone oil migration in 7 of the 57 patients (12\%), noting silicone oil at the optic nerve head $(n=2)$, retrolaminar optic nerve $(n=5)$, optic chiasm $(n=3)$, optic tract $(n=3)$, and in the lateral ventricles $(n=1)$. Attenuation values of the structures with silicone oil migration were significantly higher than those of the control regions (optic nerve head, $69.2 \pm 12.4$ vs $29.8 \pm 10.2 \mathrm{HU}, P<.001$; retrolaminar optic nerve, $59.9 \pm 11.6$ vs $30.9 \pm 8.6 \mathrm{HU}, P<.001$; optic chiasm, $74.2 \pm 11.0$ vs $25.6 \pm 6.9 \mathrm{HU}, P<.001$; optic tract, $70.1 \pm 4.7$ vs $28.7 \pm 7.2 \mathrm{HU}, P<.001)$. No significant ophthalmic or neurologic complications were documented in the patients with silicone oil migration.

CONCLUSIONS: Subretinal and retrolaminar migration of intraocular silicone oil is common. Although there were no apparent complications associated with silicone oil migration, the radiologist and clinician should be aware of this phenomenon.

ABBREVIATION: SiO = silicone oil

$\mathbf{R}$

etinal detachment is a serious medical condition that may lead to blindness if not adequately treated. ${ }^{1}$ Intraocular silicone oil (SiO) injection following vitrectomy is commonly used as an endotamponade technique to repair complex retinal detachments. ${ }^{2}$ Although considered relatively safe, the use of intraocular $\mathrm{SiO}$ is not without complications. The development of glaucoma, cataracts, and keratopathy is a known complication resulting from the diffusion of $\mathrm{SiO}$ from the vitreous cavity into adjacent structures. ${ }^{3,4}$

Received February 27, 2019; accepted after revision July 8.

From the Departments of Radiology (M.A., K.T., M.N.C., G.D.B., O.S.),

Ophthalmology (C.P.), Neurology (C.P.), Otolaryngology-Head and Neck Surgery

(O.S.), and Radiation Oncology (O.S.), Boston Medical Center, Boston University

School of Medicine, Boston, Massachusetts.

Paper previously presented, in part, as an oral presentation at: Annual Meeting of the American Society of Neuroradiology and the Foundation of the ASNR Symposium, April 22-27, 2017, Long Beach, California.

Please address correspondence to Osamu Sakai, MD, PhD, Department of Radiology, Boston Medical Center, Boston University School of Medicine, FGH Building, 3rd Floor, 820 Harrison Ave, Boston, MA 02118; e-mail:

osamu.sakai@bmc.org

Indicates article with supplemental on-line table.

http://dx.doi.org/10.3174/ajnr.A6176
Retrolaminar $\mathrm{SiO}$ migration is a lesser known complication of intraocular $\mathrm{SiO}$ injections, occurring when the $\mathrm{SiO}$ diffuses posteriorly into the optic apparatus (optic nerve, chiasm, and tract) and potentially into the subarachnoid space and ventricular system. ${ }^{5-7}$ Vision loss due to optic neuropathy has been reported as a consequence of this posterior migration. ${ }^{8}$ Although several histologic and immunohistopathologic studies have demonstrated $\mathrm{SiO}$ migration in the ophthalmologic literature, ${ }^{6,9}$ data about the prevalence and/or radiologic findings of $\mathrm{SiO}$ migration are limited. $^{5,10-21}$

The purpose of this study was to document the prevalence of retrolaminar migration of intraocular $\mathrm{SiO}$ on head $\mathrm{CT}$ and describe the clinical and radiologic findings.

\section{MATERIALS AND METHODS}

\section{Patients}

The institutional review board approved this retrospective study. The requirement to obtain written informed consent was waived. Patients with $\mathrm{SiO}$ injection treatment who underwent head CT from November 2008 to July 2018 were searched through the 
Table 1: Comparisons of clinical features between cases positive and negative for silicone oil migration

\begin{tabular}{|c|c|c|c|c|}
\hline Clinical Characteristics & $\begin{array}{l}\text { Cases Positive for } \\
\text { Migration }(n=7)\end{array}$ & $\begin{array}{l}\text { Cases Negative for } \\
\text { Migration }(n=50)\end{array}$ & $P$ & Total $(n=57)$ \\
\hline Age (mean) (yr) & $56.1 \pm 16.6$ & $57.5 \pm 18.6$ & $.942^{\mathrm{a}}$ & $57.3 \pm 18.3$ \\
\hline Sex (male/female) & $3: 4$ & $28: 22$ & $.691^{b}$ & $31: 26$ \\
\hline \multirow[t]{7}{*}{ Indication for silicone oil injection treatment } & $\begin{array}{r}\text { Diabetic retinal } \\
\text { detachment: } 4\end{array}$ & $\begin{array}{l}\text { Diabetic retinal } \\
\text { detachment: } 30\end{array}$ & & $\begin{array}{l}\text { Diabetic retinal } \\
\text { detachment: } 34\end{array}$ \\
\hline & Trauma: 1 & Trauma: 3 & & Trauma: 4 \\
\hline & $\begin{array}{l}\text { Cytomegalovirus } \\
\text { retinitis: } 1\end{array}$ & $\begin{array}{l}\text { Cytomegalovirus } \\
\text { retinitis: } 2\end{array}$ & & $\begin{array}{c}\text { Cytomegalovirus } \\
\text { retinitis: } 3\end{array}$ \\
\hline & Advanced glaucoma: 1 & Advanced glaucoma: 1 & & $\begin{array}{l}\text { Advanced glau- } \\
\text { coma: } 2\end{array}$ \\
\hline & & $\begin{array}{l}\text { Postoperative } \\
\text { hemorrhage: } 1\end{array}$ & & $\begin{array}{l}\text { Postoperative } \\
\text { hemorrhage: } 1\end{array}$ \\
\hline & & Congenital infection: 1 & & $\begin{array}{c}\text { Congenital infec- } \\
\text { tion: } 1\end{array}$ \\
\hline & & Unknown: 12 & & Unknown: 12 \\
\hline $\begin{array}{l}\text { Interval between silicone injection treatment and } \mathrm{CT} \\
\text { examination (mean) (mo) }\end{array}$ & $45.8 \pm 41.8$ & $37.4 \pm 31.7$ & $.779^{\mathrm{a}}$ & $39.2 \pm 33.5$ \\
\hline Intraocular pressure (mean) (mmHg) & $23.6 \pm 21.4$ & $15.2 \pm 5.2$ & $.291^{\mathrm{a}}$ & $16.8 \pm 10.5$ \\
\hline
\end{tabular}

a Mann-Whitney $U$ test.

${ }^{\mathrm{b}}$ Fisher exact test.

Radiology Information System of our department using a keyword "silicone." The start date of the study was set as November 2008 when we started including thin-section $(1.25 \mathrm{~mm})$ images in our routine unenhanced head CT protocol. Patients who did not have $1.25-\mathrm{mm}$ images were excluded from the study. Patients with severe motion artifacts were also excluded. The electronic medical records were evaluated for patient demographics, relevant medical history, indication of $\mathrm{SiO}$ injection treatment, indication for $\mathrm{CT}$ examinations, interval between $\mathrm{SiO}$ injection treatment and CT examination, ophthalmic examination findings, and intraocular pressure (millimeters of mercury) (Table 1 and On-line Table).

\section{CT Imaging Techniques}

All unenhanced head CT examinations were axially acquired at 5- and 1.25-mm section thickness using 64-detector row CT scanners (LightSpeed VCT; GE Healthcare, Milwaukee, Wisconsin) with soft-tissue and bone algorithm reconstructions per our institutional clinical protocol. Axial soft-tissue algorithmreconstructed 1.25 -mm images were used for analysis.

\section{Qualitative Imaging Analysis}

All images were visually evaluated for subretinal and retrolaminar migration of $\mathrm{SiO}$, which was defined as areas of increased attenuation of $\geq 1$ component of the visual tract (optic nerve head, retrolaminar optic nerve, optic chiasm, and optic tract) or within the ventricular system. Posterior migration of silicone was assessed by 2 radiologists (M.A. and K.T., with 3 and 17 years of experience in head and neck radiology, respectively) who independently reviewed the CT images; any discrepancies between the 2 radiologists were resolved during a third analysis session in which a decision was reached zby consultation with a third radiologist (O.S., with 25 years of experience in head and neck radiology).

\section{Quantitative Imaging Analysis}

Attenuation values of the intraocular $\mathrm{SiO}$ and the visually identified regions in the visual pathway and ventricles were measured in Hounsfield units. We placed single, as-large-as- possible, freeform ROIs within each region on the image with the largest cross-sectional area, avoiding partial volume effects. The attenuation value of the optic nerve was measured at the midportion of the intraorbital segment. Care was taken not to include calcification, partial volume effects, or artifacts within the ROIs. The difference between each region and its contralateral side was calculated as the absolute difference in the attenuation value. When measuring the optic chiasm or bilateral lesions, comparison with an adjacent normal structure was performed instead.

\section{Statistical Analysis}

We compared the clinical information, ophthalmologic findings, and CT features between cases positive and negative for migration. The Fisher exact test was used to compare sex, age, the interval between $\mathrm{SiO}$ injection and CT examination, intraocular pressure, and attenuation values were compared using the MannWhitney $\mathrm{U}$ test. All data for continuous variables are presented as mean \pm SD. A $P$ value $<.05$ was significant in all analyses. All statistical analyses were performed using SPSS, Version 23.0 (IBM, Armonk, New York).

\section{RESULTS \\ Patients}

Fifty-eight patients with a history of intraocular $\mathrm{SiO}$ injection who underwent unenhanced head CT examinations for various clinical indications between November 2009 and July 2018 were identified. Among these, 1 patient who did not have $1.25-\mathrm{mm}$ images was excluded. Ultimately, 57 patients ( 31 men and 26 women; mean age, 57 years; range, $18-87$ years) with intraocular $\mathrm{SiO}$ injection were included in this study. Nineteen patients were treated with intraocular $\mathrm{SiO}$ injection on the right side, and 34 patients, on the left side; 4 patients were treated on both sides.

\section{Clinical, Ophthalmic, and Radiologic Characteristics of Posterior Migration of Intraocular Silicone Oil}

The clinical and CT imaging features of $\mathrm{SiO}$ migration cases are summarized in the On-line Table. Posterior migration of 
intraocular $\mathrm{SiO}$ was identified in 7 of the 57 patients $(12.3 \%)$ (4 men and 3 women; mean age, 56 years; range, 23-71 years) with 7 eyes of the $61 \mathrm{SiO}$-treated eyes (11.5\%), with $\mathrm{SiO}$ at the optic nerve head $(n=2)$, retrolaminar optic nerve $(n=5)$, optic chiasm $(n=3)$, optic tract $(n=3)$, and in the lateral ventricles $(n=1)$. Two patients had migration to 3 locations each (optic nerve, optic chiasm, and optic tract), and 1 patient, to 4 locations (optic nerve, optic chiasm, optic tract, and lateral ventricles). Representative cases of retrolaminar $\mathrm{SiO}$ migration are shown in Figs 1-3.

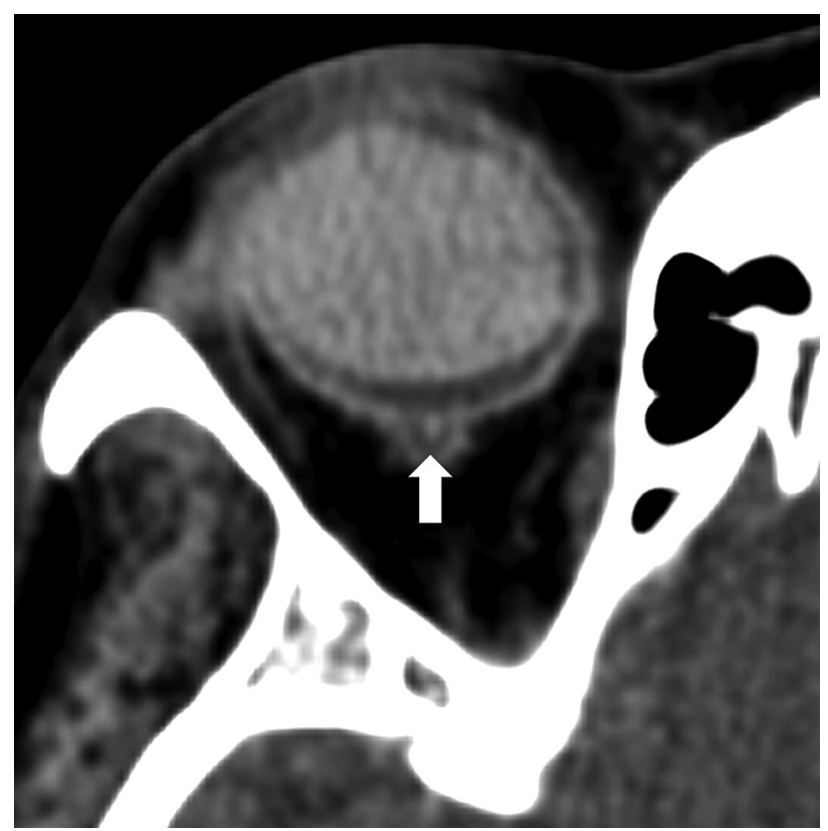

FIG 1. Subretinal silicone oil migration (case 2). Axial CT image obtained 1 week following right intraocular silicone oil injection demonstrates a punctate region of increased attenuation at the optic nerve head (arrow).

\section{Comparison of Clinical Findings between Cases Positive and Negative for Migration}

Clinical characteristics in cases positive and negative for migration are summarized in Table 1.

We had recorded vision for 34 of the 57 patients in the cohort (4/7 patients positive for $\mathrm{SiO}$ migration and $30 / 50$ negative for $\mathrm{SiO}$ migration). For the cases positive for $\mathrm{SiO}$ migration, 1 patient had 20/400 vision, 1 had finger-counting vision, and 4 had no light perception vision. For the $\mathrm{SiO}$ cases negative for migration, 3 patients had 20/400 vision, 3 had finger-counting vision, 5 had hand motion vision, 8 had light perception vision, and 11 had no light perception vision. On the basis of the available acuity data, there did not appear to be a difference between the cohorts positive and negative for $\mathrm{SiO}$ migration $(P=.517)$. The best-corrected acuity in both groups ranged from 20/400 to no light perception vision.

There was no significant difference in age and sex between cases positive and negative for migration $(P=.942$, .691, respectively). The interval between silicone injection treatment and CT examination was not significantly different between cases positive and negative for migration ( $45.8 \pm 41.8$ versus $37.4 \pm 31.7$ months, $P=$.779). Retrolaminar $\mathrm{SiO}$ migration was present as early as 1 week and as late as 4 years after injection. Intraocular pressure elevation had been documented in 3 patients with $\mathrm{SiO}$ migration. Intraocular pressure on the side of silicone injection treatment showed no significant difference between cases positive $(n=5)$ and negative for migration $(n=20)(23.6 \pm 21.4$ versus $15.2 \pm 5.2 \mathrm{~mm} \mathrm{Hg}, P=.291)$.

\section{Quantitative CT Analyses}

The attenuation value of intraocular $\mathrm{SiO}$ was $91.5 \pm 12.5 \mathrm{HU}$, with no significant difference between cases positive and negative for migration $(94.1 \pm 2.2$ versus $91.1 \pm 13.3 \mathrm{HU}$, $P=.228$ ). Attenuation values of the normal structures were not significantly different between the silicone injection side and the contralateral side (optic nerve head, $30.6 \pm 13.8$ versus $31.4 \pm 9.5 \mathrm{HU}, P=.173$; retrolaminar optic nerve, $34.4 \pm$ 12.9 versus $30.4 \pm 7.6 \mathrm{HU}, P=.206$; optic tract, $31.5 \pm 11.5$ versus $27.9 \pm 7.1 \mathrm{HU}, P=.108$; whole region $32.2 \pm 12.8$ versus $30.0 \pm 8.2 \mathrm{HU}, P=.717)$. Attenuation values of the regions with $\mathrm{SiO}$ migration were significantly higher than those in the control regions (optic nerve head, $69.2 \pm 12.4$ versus $29.8 \pm$ 10.2 HU, $P<.001$; retrolaminar optic nerve, $59.9 \pm 11.6$ versus $30.9 \pm 8.6$ HU, $P<.001$; optic chiasm, $74.2 \pm 11.0$ versus $25.6 \pm 6.9 \mathrm{HU}, P<.001$; optic tract, $70.1 \pm 4.7$ versus $28.7 \pm 7.2 \mathrm{HU}$, $P<.001$; whole region, $67.0 \pm 10.9$ versus $29.2 \pm 8.6 \mathrm{HU}, P<.001$ ) (Table 2 ). One case showed high attenuation in both lateral ventricles (right side, 80.1 HU; left side, 78.8 HU) (Fig 3).

\section{DISCUSSION}

Intraocular $\mathrm{SiO}$ injection is widely used in the management of complex retinal chiasm (case 6). $A$ and $B$, Axial CT images 1 year after left intraocular silicone oil injection demonstrate abnormal increased attenuation of the intraorbital segment of the left optic nerve $(A$ arrow) and nodular increased attenuation at the optic chiasm ( $B$, arrow). 

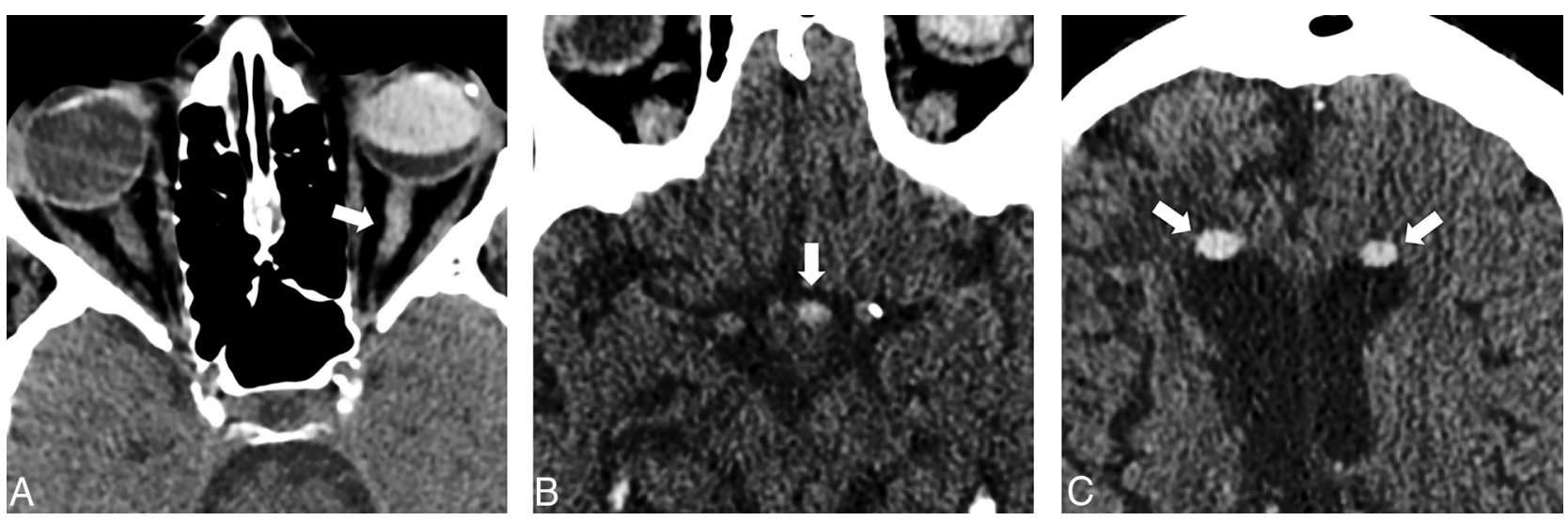

FIG 3. Retrolaminar silicone oil migration to the retrolaminar optic nerve and optic chiasm and within the lateral ventricles (case 4). Axial CT images 6 years after left intraocular silicone oil injection demonstrate tubular increased attenuation of the intraorbital segment of the left optic nerve ( $A$, arrow), nodular hyperattenuation in the optic chiasm/optic tract ( $B$, arrow), and biconvex hyperattenuation in the nondependent regions of the frontal horns of the lateral ventricles (C, arrows).

Table 2: Comparisons of attenuation values in the visual tract structures between silicone oil migration lesions and normal regions $^{a}$

\begin{tabular}{lccc}
\hline $\begin{array}{c}\text { Structures (Lesion: } \\
\text { Normal) }\end{array}$ & $\begin{array}{c}\text { Silicone Oil } \\
\text { Migration Lesion }\end{array}$ & $\begin{array}{c}\text { Normal } \\
\text { Region }\end{array}$ & $\boldsymbol{P}^{\mathrm{b}}$ \\
\hline Optic head (2:112) & $69.2 \pm 12.4$ & $29.8 \pm 10.2$ & $<.001$ \\
Optic nerve (5:119) & $59.9 \pm 11.6$ & $30.9 \pm 8.6$ & $<.001$ \\
Optic chiasm (3:53) & $74.2 \pm 11.0$ & $25.6 \pm 6.9$ & $<.001$ \\
Optic tract (3:109) & $70.1 \pm 4.7$ & $28.7 \pm 7.2$ & $<.001$ \\
\hline
\end{tabular}

${ }^{\mathrm{a}}$ Data are presented as means. Attenuation values are in Hounsfield units.

${ }^{\mathrm{b}}$ Mann-Whitney $U$ test.

detachments and is considered relatively safe and effective in vitreoretinal surgery. ${ }^{2,22,23}$ Despite its relatively safe profile, $\mathrm{SiO}$ may diffuse into various ocular and extraocular tissues, resulting in complications such as glaucoma, keratopathy, and cataract formation. ${ }^{3,4}$ It may also diffuse posteriorly into the subretinal space, optic nerve, optic chiasm, subarachnoid spaces, and potentially the ventricular system. This phenomenon, first described by Ni et al, in $1983,{ }^{6}$ is known as subretinal or retrolaminar migration of intraocular SiO. The term "retrolaminar" refers to the migration of silicone droplets past the lamina cribrosa, the main structural element where the retinal ganglion cell axons and the central retinal vein and artery enter or exit the eye. ${ }^{24}$ Although many case reports have described retrolaminar $\mathrm{SiO}$ migration, no radiologic studies addressing the frequency or the radiologic features of this phenomenon were found. We believe this is the first study to show the frequency of retrolaminar $\mathrm{SiO}$ migration on CT images along with clinical correlation. In this study, migration was detected in $12 \%$ of patients, which is comparable with histopathologic studies performed on enucleated eyes with silicone injection (11\%-24\%). ${ }^{9,25,26}$ Migration of $\mathrm{SiO}$ was noted at the optic nerve head, retrolaminar optic nerve, optic chiasm, optic tract, and in the lateral ventricles, and those findings were confirmed by quantitative analyses.

Retrolaminar $\mathrm{SiO}$ migration is believed to be a benign phenomenon usually detected incidentally on cross-sectional imaging. ${ }^{5}$ However, visual symptoms have been reported and are thought to be related to silicone-induced optic neuropathy secondary to macrophage infiltration..$^{9,26,27}$ In our series, no significant neuro-ophthalmologic or neurologic complications related to SiO migration have been documented in the medical records.

The exact mechanism of $\mathrm{SiO}$ migration remains uncertain. The role of elevated intraocular pressure in $\mathrm{SiO}$ migration was first described by Shields in 1989. ${ }^{5}$ However, not all of our cases or all the published cases were associated with pre-existing elevated intraocular pressure. ${ }^{28}$ Intraocular pressure at the side of $\mathrm{SiO}$ injection treatment in cases positive for migration was slightly higher than that in cases negative for it in our results, though the difference was not statistically significant.

More recent studies suggest that $\mathrm{SiO}$ may infiltrate or diffuse directly into the retinal layers and then into the optic nerve by infiltrating along the retinal nerve fibers through the lamina cribrosa. In 2006, Kuhn et $\mathrm{al}^{29}$ proposed that optic pits (congenital abnormalities of the optic nerve head) may serve as an entry point for the retrolaminar migration of $\mathrm{SiO}$. This infiltration may be facilitated by increased intraocular pressure. ${ }^{5}$ The entry of $\mathrm{SiO}$ into the subarachnoid space and then the ventricular system may be explained by passage of the $\mathrm{SiO}$ droplets directly from the vitreous space or from the optic nerve into the perioptic subarachnoid spaces through the perivascular spaces of the central retinal vessels where they pierce the optic nerve. ${ }^{5,8,15}$ The diffusion of $\mathrm{SiO}$ into the ventricular system is less frequently encountered than into the optic nerve. Boren et $\mathrm{al}^{5}$ found 15 case reports of intraventricular $\mathrm{SiO}$.

Silicone oil is usually reported as hyperattenuating on CT images with attenuation ranging between 60 and $140 \mathrm{HU}$, depending on the viscosity and the location of the SiO. ${ }^{10,30}$ Our qualitative results, supported by quantitative analysis, showed that attenuation values of the regions with $\mathrm{SiO}$ migration were significantly higher than those in control regions. At the optic chiasm, only ipsilateral nodular high attenuation was detected. Within the ventricular system, the SiO characteristically floats in nondependent locations because of its lower specific gravity relative to CSF. On MR imaging, $\mathrm{SiO}$ has been reported to be hyperintense relative to CSF or contralateral normal vitreous on T1weighted images. MR imaging may detect $\mathrm{SiO}$ droplets as small as $1 \mathrm{~mm}^{3}$. 31 
Radiologists should be aware of the occurrence of SiO migration, though it is relatively rare and often without clinical symptoms. Knowledge of the appearance and common locations on CT is important to avoid misdiagnosis of subarachnoid or intraventricular hemorrhage or tumor.

Our study has several limitations. Because posterior migration of $\mathrm{SiO}$ is relatively rare, the number of cases positive for migration was small, limiting the statistical power and accuracy of the prevalence. Second, this was a retrospective study that may have been subject to selection bias. Determination of the timing of and chronologic changes in migration was not possible for many patients because imaging follow-up after intraocular injection or after identifying migration is not routinely performed. A detailed ophthalmologic examination including intraocular pressure was not available in all cases, and none had histopathologic confirmation.

\section{CONCLUSIONS}

Retrolaminar migration of intraocular $\mathrm{SiO}$ is a common phenomenon. Radiologists should be aware of its occurrence and familiar with its imaging characteristics and patterns of migration to prevent misdiagnosis.

Disclosures: Margaret M. Chapman-UNRELATED: Consultancy: Boston Imaging Core Lab. Glenn D. Barest_UNRELATED: Consultancy: Boston Imaging Core Lab. Osamu Sakai-UNRELATED: Consultancy: Boston Imaging Core Lab.

\section{REFERENCES}

1. Rothova A, Suttorp-van Schulten MS, Frits Treffers W, et al. Causes and frequency of blindness in patients with intraocular inflammatory disease. Br J Ophthalmol 1996;80:332-36 CrossRef Medline

2. Cockerham WD, Schepens CL, Freeman HM. Silicone injection in retinal detachment. Arch Ophthalmol 1970;83:704-12 CrossRef Medline

3. Federman JL, Schubert HD. Complications associated with the use of silicone oil in 150 eyes after retina-vitreous surgery. Ophthalmology 1988;95:870-76 CrossRef Medline

4. Riedel KG, Gabel VP, Neubauer L, et al. Intravitreal silicone oil injection: complications and treatment of 415 consecutive patients. Graefe's Arch Clin Exp Ophthalmol 1990;228:19-23 CrossRef Medline

5. Boren RA, Cloy CD, Gupta AS, et al. Retrolaminar migration of intraocular silicone oil. J Neuroophthalmol 2016;36:439-47 CrossRef Medline

6. Ni C, Wang WJ, Albert DM, et al. Intravitreous silicone injection: histopathologic findings in a human eye after 12 years. Arch Ophthalmol 1983;101:1399-1401 CrossRef Medline

7. Filippidis AS, Conroy TJ, Maragkos GA, et al. Intraocular silicone oil migration into the ventricles resembling intraventricular hemorrhage: case report and review of the literature. World Neurosurg 2017;102:695.e7-95.e10 CrossRef Medline

8. Papp A, Kiss EB, Tímár O, et al. Long-term exposure of the rabbit eye to silicone oil causes optic nerve atrophy. Brain Res Bull 2007;74:130-33 CrossRef Medline

9. Wickham L, Asaria RH, Alexander R, et al. Immunopathology of intraocular silicone oil: enucleated eyes. Br J Ophthalmol 2007;91:25357 CrossRef Medline

10. Mathews VP, Elster AD, Barker PB, et al. Intraocular silicone oil: in vitro and in vivo $\mathrm{MR}$ and CT characteristics. AJNR Am J Neuroradiol $1994 ; 15: 343-47$
11. Chiao D, Ksendzovsky A, Buell $\mathrm{T}$, et al. Intraventricular migration of silicone oil: a mimic of traumatic and neoplastic pathology. $J$ Clin Neurosci 2015;22:1205-07 CrossRef Medline

12. Mathis S, Boissonnot M, Tasu JP, et al. Intraventricular silicone oil: a case report. Medicine (Baltimore) 2016;95:e2359 CrossRef Medline

13. Chang CC, Chang HS, Toh $\mathrm{CH}$. Intraventricular silicone oil. J Neurosurg 2013;118:1127-29 CrossRef Medline

14. Fangtian D, Rongping D, Lin Z, et al. Migration of intraocular silicone into the cerebral ventricles. Am J Ophthalmol 2005;140:156-58 CrossRef Medline

15. Eller AW, Friberg TR, Mah F. Migration of silicone oil into the brain: a complication of intraocular silicone oil for retinal tamponade. Am J Ophthalmol 2000;129:685-88 CrossRef Medline

16. Mayl JJ, Flores MA, Stelzer JW, et al. Recognizing intraventricular silicone. Emerg Radiol 2018;25:215-18 CrossRef Medline

17. Bobba S, Fox OJK, Lee MB, et al. Contiguous silicone oil migration from the vitreous cavity to the optic tract. J Neuroophthalmol 2017;37:464-65 CrossRef Medline

18. Gnanalingham J, Mcreary R, Charles S, et al. Migration of intraocular silicone oil into brain. BMJ Case Rep 2017;2017 CrossRef Medline

19. Ascaso FJ, Grzybowski A. Subarachnoidal migration of intraocular silicone oil. Acta Neurochir (Wien) 2017;159:807 CrossRef Medline

20. Cebula H, Kremer S, Chibbaro S, et al. Subarachnoidal migration of intraocular silicone oil. Acta Neurochir (Wien) 2017;159:34748 CrossRef Medline

21. Potts MB, Wu AC, Rusinak DJ, et al. Seeing floaters: a case report and literature review of intraventricular migration of silicone oil tamponade material for retinal detachment. World Neurosurg 2018;115:201-05 CrossRef Medline

22. Watzke RC. Silicone retinopiesis for retinal detachment: a long-term clinical evaluation. Arch Ophthalmol 1967;77:185-96 CrossRef Medline

23. Azen SP, Scott IU, Flynn HW Jr, et al. Silicone oil in the repair of complex retinal detachments: a prospective observational multicenter study. Ophthalmology 1998;105:1587-97 CrossRef Medline

24. Jonas JB, Berenshtein E, Holbach L. Anatomic relationship between lamina cribrosa, intraocular space, and cerebrospinal fluid space. Invest Ophthalmol Vis Sci 2003;44:5189-95 CrossRef Medline

25. Biswas J, Verma A, Davda MD, et al. Intraocular tissue migration of silicone oil after silicone oil tamponade: a histopathological study of enucleated silicone oil-filled eyes. Indian J Ophthalmol 2008;56:42528 CrossRef Medline

26. Budde M, Cursiefen C, Holbach LM, et al. Silicone oil-associated optic nerve degeneration. Am J Ophthalmol 2001;131:39294 CrossRef Medline

27. Mukai N, Lee PF, Schepens CL. Intravitreous injection of silicone: an experimental study, II: histochemistry and electron microscopy. Ann Ophthalmol 1972;4:273-87 Medline

28. Knecht $\mathrm{P}$, Groscurth $\mathrm{P}$, Ziegler $\mathrm{U}$, et al. Is silicone oil optic neuropathy caused by high intraocular pressure alone? A semi-biological model. Br J Ophthalmol 2007;91:1293-95 CrossRef Medline

29. Kuhn F, Kover F, Szabo I, et al. Intracranial migration of silicone oil from an eye with optic pit. Graefes Arch Clin Exp Ophthalmol 2006;244:1360-62 CrossRef Medline

30. Hruby PM, Poley PR, Terp PA, et al. Headaches secondary to intraventricular silicone oil successfully managed with ventriculoperitoneal shunt. Retin Cases Brief Rep 2013;7:288-90 CrossRef Medline

31. Kiilgaard JF, Milea D, Løgager V, et al. Cerebral migration of intraocular silicone oil: an MRI study. Acta Ophthalmol 2011;89:522-25 CrossRef Medline 